\title{
CREATING ORGANIZATIONAL COMMITMENT THROUGH SPIRITUAL LEADERSHIP: MEDIATING EFFECT OF MEANING AT WORK
}

Elif BAYKAL ${ }^{1}$

\author{
Received (Başvuru Tarihi): 19/04/2019
}

Accepted (Kabul Tarihi): 01/06/2019

Published Date (Yayın Tarihi): 26/06/2019

\begin{abstract}
Fierce competition and oppressing business life of 21 st century has given birth to changes in business life and caused some troubles on the side of employees. Unsatisfaction regarding daily working habits has given way to increasing demands of employees regarding a more humane and more meaningful work. In this point, workplace spirituality and spiritual leadership come to scene as possible remedies for the meaninglessness and disappointment of modern employees. In the study, it is hypothesized that spiritual leadership has a positive effect on organizational commitments of employees and the sense of meaning act as a mediator in this relationship. In this paper, we will first explain the spiritual constructs like workplace spirituality and spiritual leadership. And than we will explain our research regarding the relationship among spiritual leadership, sense of meaning and organizational commitment in details. In order to test the relationships in our model a field research has been applied on 800 turkish academicians by using online and face to face surveys. And 190 usable answers have been obtained. Results of the study has been analyzed by using SPSS. 22 program.
\end{abstract}

Keywords: Spiritual Leadership, Workplace Spirituality, Meaning, Organizational Commitment

Jel Codes: M12, M54, L84

\section{SPİRITÜEL LİDERLİK ARACILIĞI İLE ÖRGÜTSEL BAĞLILIK YARATMA: İSTE ANLAM DUYGUSUNUN ARACI ETKİSi}

$\ddot{o} Z$

21. yüzyılda, şiddetli rekabet ve baskıcı iş ortamları, çalışanların iş hayatında önemli değişikliklere ve sıkıntılara sebep olmuştur. Günlük çalışma alışkanlıklarına ilişkin memnuniyetsizlik, çalışanların daha insancıl ve anlamlı bir çalışma konusundaki taleplerinin artmasına yol açmıştır. Bu noktada, işyeri maneviyatı ve spiritüel liderlik, modern çalışanların anlamsızlığı ve hayal kırıklklarını gidermek için potansiyel çareler olarak ortaya çıkmıştır. Çalışmada, spiritüel liderliğin çalışanların örgütsel bağlılıkları, iş hayatında anlam duygusu üzerinde olumlu bir etkiye sahip olduğu ve anlam duygusunun söz konusu ilişkide aracı etkiye sahip olduğu varsayılmıştır. Bu çalışmada, önce işyeri maneviyatı ve manevi liderlik gibi manevi yapılar ele alınacak, daha sonra da spiritüel liderlik, anlam duygusu ve örgütsel bağlılık arasındaki ilişki ile ilgili araştırmamızı detaylarıyla açıklanacaktır. Modelimizdeki ilişkileri test etmek için, çevrimiçi ve yüz yüze anketler kullanarak 800 Türk akademisyene saha araştırması yapılmıştır. Ve 190 kullanışlı cevap elde edilmiştir. Çalışmanın sonuçları SPSS 22 programı kullanılarak analiz edilmiştir.

Anahtar Kelimeler: Spiritüel Liderlik, Isşyeri Maneviyatı (Ruhsallığı), Anlam, Örgütsel Bă̆lllık

Jel Kodlart: M12, M54, L84

${ }^{1}$ Assistant Professor, Istanbul Medipol University, enarcikara@medipol.edu.tr 


\section{INTRODUCTION}

In 21st century, competitive business life and ever demanding structure of the competition necessitate more empowered and flexible organizations rather than classical centralized, breaucratic, standardized, and highly formalized organizations led by fear and extrinsic motivators. Financial failures, bankruptcies and crises of modern age have lowered the employees morale. Due to changing social conditions, people are more capable of satisfying their psychological needs such as affliation, friendship and membership. The need to resolve these needs in the business environment and the need to reconnect, and the increasing popularity of religious and spiritual doctrines that emphasize meditation and the serenity of the soul have given way to more spirit-focused managerial demands (Narcikara E. B., 2018: 12). Contemporary business life might create a necessity for spiritual journey of the modern employees. On the one hand, according to Lowery (2005), 21st century has witnessed respect for the individual rights to live and express spirituality. Especially emphasis on religious "neutrality" has become popular and pervasive in the realms of politics and law. In the realm of politics, such neutrality gives rise to a relativistic approach, that is quite important for giving meaning to the significance of spiritual leadership in secular structures (Frisdiantara and Sahertian, 2012). In 21st century secular discourse adopted some of the ethical codes of religious tradition and spiritualy has become a popular realm of study (Crossman, 2007). And leadership literature has turned into a more value-based realm of study unlike traditional leadership approaches that are often based on cost-benefit assumptions" (Chen and Li, 2012: 240).

The previous leadership theories mostly focus on the followers' internal needs and they lack a focus on higher order needs and the relationships between the inner values of followers, and the organization's value systems are not adequately addressed (Fry, 2003; Reave, 2005). Spiritual leadership is beneficial in understanding the link between holistic integrity of individuals, especially their chance of experiencing their inner values at work and positive organizational outputs resulting from this integrity. In this article, spiritual leadership is the focal point of the study. It is regarded as an intrinsic motivator that makes individuals feel motivated, alive, hopeful and energized in harmony with their own selves and connected with their work. As theorized by Fry (2003) we assume that spiritual leadership encompasses leadership behaviors that intrinsically motivate followers through spiritual well-being, vocational calling and organizational membership, thus creating a sense of meaning at work. 
And we assumed that this experience of meaning at work will contribute to organizational commitment perceptions of individuals.

\section{SPIRITUALITY}

Spirituality is a dynamic mechanism through which people willingly attempt to discover their capacity and establish a personal link with a superior power that may be God or some higher power else (Wulff, 1996). Coma (2007) argued that spirituality can be defined as researching sense of meaning and reaching the person's own essence in life. He claimed that the meaning of life and death is a universal and sacred phenomenon in which people understand the meaning of life through the relationships they establish with themselves and others. Purpose of spirituality is provision of meaningful exploitation of one's own spiritual salvation, which does not necessarily come about through religion. The concept of spirituality, which is the subject of spirituality and workplace spirituality, explains a concept independent of religion and it is perceived as a connection with any higher power or emotion that provides the spiritual satisfaction of the individual including religion (Narcikara, 2018: 14). In spirituality literature, workplace spirituality is the way people consider work as an occasion, as a spiritual way of developing and contributing to society. It includes values such as interest, compassion, support to others, intrinsic integrity and honesty towards one's self and the environment (Narcikara, 2017: 51). The main purpose of the workplace spirituality is to contribute to the positive realization and positive relations with the environment. In this sense, spirituality is used in a similar sense to the meaning of the stage of self-realization, which is the top step of Maslow's human development. That is to say, it is an effort of the employees to find meaning in their jobs. Workplace spirituality focuses on the human's spiritual characteristics and needs in the work environment and thus enables employees to make sense of their lives in the work environment. In order to be able to talk about the workplace spirituality, it is very important that the internal world of those at work is fed by a meaningful business in a social context.

Spirituality fills an important gap in a person's life, and in most cases carries out a function similar to religion in filling this void. Religion and spirituality overlap significantly on certain basic issues. For example in both religion and spirituality, the center is a search for sacred namely search for meaning. And the concept of spirituality is frequently confused with religion. While religion is related to the highly structured belief systems, spirituality is defined as the closeness to God or similar national power and interdependence with the outside world 
and other beings. While religion includes the acceptance of a great, divine or sacred being, submission, obedience and worship, contemporary definitions of spirituality vary from religion to a broader range (Narcikara, 2017: 48). In fact, spirituality is not bounded with individual's religious belief, world view, philosophy of life, or the values he cares. Sometimes people may want to experience their spirituality by using tools such as meditation. Especially in recent years, the intensive interest in the Far East, yoga and relaxation exercises such as meditation and relaxation exercises are the alternative ways to experience spirituality. For employees who are interested in far eastern teachings to relax and reach serenity, yoga courses or meditation sessions have started to take place in many companies. And historically, in the last 50 years, spirituality has become a subject that has been intensely emphasized and attracted attention, and it has become a term that has been pronounced in a separate way from religion and has different meanings (Zinnbauer et al., 1997). According to Zinnbauer (1997) While religion is related to a largely structured belief system, spirituality is defined as the closeness to God or similar great power and interdependence with the external world and other beings. Since previously, traditional religious groups mostly used this term in their religious discourses, the term is often mixed with religion is a concept that results in confusion. And nowadays, spirituality is considered as a subject that is more related to the individual field, which can be identified with personal transcendence, spiritual sense and sensitivity to life whereas religion is more narrowly associated with religious institutions, formal structured and defined belief systems, worship and rituals.

Although it is mostly related to inner facts and inner life of individuals, spirituality is not a concept unrelated with modern corporate life. The term workplace spirituality is helpful in understanding function of spirituality in business. According to Fry (2003), one of the most important names focused on spiritual leadership, the difficulties in working conditions and the environment of insecurity created by modern business have forced employees to seek deeper meaning and loyalty to life and have created workplace spirituality. Anyway, many concepts of workplace spirituality involves finding meaning in the business environment, having a purpose in life and being connected to other people (Giacalone \& Jurkiewicz, 2003). According to Fry (2003), spirituality is a link with a higher power and affects the ways that an individual acts. It helps individuals create a meaningful atmosphere in both their private and business lives. And spiritual leadership is an important managerial tool in creating a meaningul atmosphere wherein spiritual values of individuals are appreciated and can be lived freely. 


\section{SPIRITUALITY AND MEANING}

The traditional sense of leadership in traditional, bureaucratic, hierarchical and central organizations cannot overcome the differentiated needs of the employees, especially regarding the provision of spiritual satisfaction and balance of the individual. At this point, workplace spirituality and spiritual leadership style, which are practically reflections of spirituality and spirituality in the business environment, are seen as an important help in solving problems in today's business life (Narcıkara, 2018 : 12). It includes an effort to find one's main purpose in his life, to have a powerful link with others at workplace, and to have an alignment among one's essential beliefs, convinctions regarding life and core values of his organization. As a managerial concept workplace spirituality has its roots in the term spirituality and it is conceived as a multidimensional concept, encompassing a unique interaction of one's own self with his/her own values and a unique meaning adopted through a transcendental practice of one's work (Baykal and Zehir, 2018: 124). One of the most prominent properties of workplace spirituality is experiencing a considerable level of meaning and purpose at work. This aspect tries to explain how people handle their daily work individually (Milliman, Czaplewski and Ferguson, 2003: 429) and assumes that employees have the inclination to engage in tasks that contributes to much higher levels of meaning in their lives (Ashmos and Duchon, 2000). It is closely related to expressing and experiencing one's inner life needs one's deep feelings by seeking meaningful work.

\section{SPIRITUAL LEADERSHIP}

Spiritual leadership is an important antecedent of workplace spirituality. As mentioned before, two important properties of workplace spirituality are; experiencing transcendence and the need for social membership (Fry, 2003). In Fry’s (2003) approach of spiritual leadership, calling demonstrates some kind of a transcendence wherein individual at work makes a difference through service to other people and creates meaning in life. Membership includes fundamental psychological needs that are to be met. This perception of being understood and consented by other people creates a sense of connectedness through group social relationships and thus membership (Fry, 2003: 704). Spiritual leadership is a significant antecedent of workplace spirituality. Supporting this point of view, in the extant literature, we can come accross studies confirming this relationship. For example in Afsar et al.'s (2016) study in Thailand, a positive effect of spiritual leadership on workplace spirituality has been assumed. 
Results confirmed the existence of this positive relationship and showed that this relationship becomes even stronger incase subordinates' perceived organizational support and perceived organziational care are higher. Similarly, in her study in turkish context Gündüz (2017) confirmed that spiritual leadership, has a diminishing effect on organizational cynicism.

According to Pfeffer (2003), workplace spirituality meets the four fundamental needs of people at work: (1) meaningful work that permits progress and development (2) feeling of purpose, (3) being connected to other collegues and having positive social interactons with them, and (4) having integration in life, living in harmony one's essential nature. The first two elements closely effect to dimension of calling in spiritual leadership theory of Fry (2003) and the other two dimensions to membership dimension. In fact, all of these principles ensures that indivuduals live a life with high levels of awareness by knowing themselves, respecting others' believes and ideas, being as trusting as they can be. Without doubt, this is often possible by being able to maintain a spiritual practice in the workplace for example engaging in prayer, mediation, spending time in nature. Fry (2003) claims that spirit is the most important energizing power in individuals and it can be conceived as an effective force in identity formation. Spirituality has a potential to create a link intangible truths of the self and the meaning that individuals load to their lives at workplaces. Moreover, meaning at work gives employees the ease to cope with distressed environment of competitive contemporary business life that is highly complex and turbulent.

According to DeVost (2010) there is a meaningful relationship between a leader's spirituality and the spirituality of a workplace. Leader's tendency to open space for spirituality results in a more integrated, namely a more holistic work atmosphere that serves employees necessary means to maket hem engage in their jobs with their whole selves, namely with both their souls and minds. Cultivating meaning at work is possible with a limited number of leadership forms. In his model Fry (2003) emphasizes the need for spiritual leaders in creating a vision in which followers perceive calling resulting in meaningful lives and makes difference. Supporting power of spiritual leadership in creating sense of meaning, Paloutzian et al. (2003) claim that when work is considered as a calling and as a good occasion to work for God or any other kind of high level power, work-related actions of individuals take on noteworthy importance and meaning. And in this study, we supposed that this sense of meaning can even increase organizational commitments of individuals. 
Fairholm's (1996) model regarding spiritual leadership was one of the earliest models on spiritual leadership including; a corporate philosophy emphasizing development, mutual trust and concern for others, group orientedness, and interior integrity. Fairholm (1996) claims that work is an important source of values in contemporary corporations. Thus, the need for an integrated organizational culture, proper kinds of leaders and coherant organizational processes in which individuals' needs and values can be met. As mentioned before spiritual leadership is an important tool in answering search for meaning of contemporary employees. And many leadership schlars have confirmed the connection between leadership styles, spirituality at work and meaning (Greenleaf, 1977, Kouzes and Posner, 2002, Fry. 2003). Later Fry (2003) proposed a considerable effect of spirituality on leadership. This theory has its roots in theories athat suggests a causal model regarding leaders' personal values, and behaviors and follower's specific demands regarding spiritual survival act as antecedents of positive outcomes including organizational commitment and more productive organizational members. Accordin to Fry (2003) two factors are inevitable if spiritual leadership is applied in a work setting; (1) The leader and the employees should feel the sense of meaning about their work and thus make sense of all their lives. They have a purpose in their lives and make a difference. (2) To have an organizational climate wherein members are in a relationship of mutual love and respect and are closely involved. According to Markow and Klenke (2005) this model offers an intrinsic motivation approach incorporating leaders' charachteristic behaviors and involves two main spiritual demands of followers, namely, calling and social connection.

In this model, vision sets the overall direction of the organization (Fry and Cohen 2009) and creates value congruence, thus fostering higher employee commitment and mor eproductve organizations (Fry, et. al. 2017). On the one hand, hope/faith is about the convinction that organization's goals can be and will be attained (Fry et. al. 2017). Moreover, altruistic love is the harmony, resulting from intimate and caring leadership (Fry, 2003: 712). Moreover, calling refers to making changes by serving people and by this way creates meaning and goal for the life (Fry et.al. 2017:713). And membership creates a sense of belonging and a sense of being understood and approved (Fry 2003, 2005a). Kriger and Seng (2005) also focused on spiritual leadership.Their model is quiet different from the previous models in that religion is an important part of it, different from the prior models in which religion is not an important element. Fry (2003) also thinks that fundamental common point between spirituality and religion is altruism and unrequited love to other people, in this sense the teachings of spiritual 
doctrines and common religions are remarkably common. Later, Fernando and Nilakant (2008) also focused on spiritual leadership by revealing that self-growth is an important component of spiritual leaders. By the help of self growth leaders embrace self-reflection and by the help of self-reflection they open the path for connecting with the high purpose namely, selfactualization. And according to the Chen and Yang's (2012) spiritual leadership model spiritual leadership consists of important dimensions that feed the sense of meaning in the business environment encompassing; vision, hope and belief, altruism, meaning and calling and membership. The first three dimensions of this model are vision, hope/belief, and altruism. The first three elements of the spiritual leadership affect the last two elements in a positive way and create the sense of meaning and belonging in the business environment and the organizational citizenship behaviors such as the employees' self-sacrificing and conscientious behavior. According to Chen and Yang (2012); organization's vision and goals nurture the meaning world of employees. Later, Vandenberghe (2011) also developed a model focusing on spirituality at workplace and its possible results on organizational commitment. In their model, it is claimed that organizational commitment level is effected by employees' individual spirituality and the general climate of the organization.

In fact, nearly all spiritual leadership models embrace a stakeholder approach in explaining organizations as structures composed of different layers all of whom have importance in the overall productivity of the organizations (Jones et al., 2007). Fry and Cohen (2008) claims that the relationship between vision and stakeholders creates a kind of value congruence among leaders and followers eventually contributing to employee well-being and organizational identification and commitment that lead to performance excellence and answers the search for meaning.

\section{ORGANIZATIONAL COMMITMENT}

Organizational commitment explains the extent that employees feel loyalty to their organization, they recognize their organization's rules and values. As Sreejesh and Tavleen (2011) suggests organizational commitment can be considered as a matter of personal choice made by a rational judgment. Namely, it is a rational decision made by employees regarding the decision to stay in ther organization and protect their occupational assets encompassing salary, position, fringe benefits benefits etc. (Mousa and Alas, 2016: 249). Higher organizational commitment, mostly result in stronger ties with the organization's vision and 
goals that causes lower turnover ratios (Sušanj and Jakopec, 2012). Organizational commitment explains the psychological force binding people to specific targets. That unique force has the potential to be understood through various mindsets reflecting different elements of the commitment concept (Vandenberghe, 2011: 213). Meyer and Allen (1991) suggests that organizational commitment is composed of three main elements; emotional commitment, referring to an pindividual's emotional attachment to the company he/she is working for, his/her strong affective binds with the organization; (b) continuous commitment, the intent to stay in his/her organization owing to one's positive beliefs about it, namely considering continuing to work in the organziation nore advantageous; and lastly normative commitment can be explained as an individual's intent to stay in the organization owing to the feelings of obligation that he/she feels towards it.

Workplace spirituality can be recognized as a potential antecedent of organizational stability and organizational performance due to its influences on affective and normative organizational commitments due to the fact that for individuals spirituality is an affective and cognitive experience (Campbell and Hwa, 2014). Being aware of the spiritual tendencies of their organization and having the opportunity to live one's own spirituality people led by spiritual leadership can be more committed to their organization. Although scarce in number we can come accross some empirical studies regarding the relationship between spiritual leadership behavior and organizational commitment. For instance; in their study Kolodinsky et al. (2008) confirmed the positive impact of workplace spirituality on job satisfaction and employee identification to the organizations. Later, in Campbell and Hwa's (2014) research, the possible positive effects workplace spirituality on 376 academicians in Malaysia. The results showed positive effects of spirituality on normative and affective commitment.

\section{HYPOTHESIS}

In the extant literature there are studies on spiritual leadership and organizational behavior constructs like commitment, loyalty and attachment. For example; study applied by Alimudin et. al. in 2017 in Indonesian context on 500 people working in a hospital showed that spiritual leadership positively effects the organizational culture. A positive significant relationship was seen between organizational culture and employee loyalty, and a positive but insignificant relationship was between spiritual leadership and employee loyalty. Later, study conduced by Chen and $\mathrm{Li}$ (2012) on 591 people from diverse organizations in China and Taiwan. This study confirmed the positive effect of calling and membership on organizational 
results like productivity, Organizational commitment and organizational citizenship. Mansor et al. (2013) also examined the spiritual leadership and commitment relationship. They applied their study in Malaysia. 203 respondents applied to the study and results confirmed a positive relationship between spritiual leadership and organizational commitment. And in Egyptian context Mousa and Alas (2016) examined workplace spirituality and commitment relationship. Their results showed that meaningful work and membership significantly effect organizational commitment. Similarly, Fini and Abmal examined the relationship among individual happiness, workplace spirituality and organizational commitment in teachers. Their results confirmed the supposed positive relationship between workplace spirituality and organizational commitment. Moreover, Fry et al.'s (2017) study applied on 27 Baldrige award recipients showed that spiritual leadership's significant impact on commitment, productivity and life satisfaction of individuals.

Fry's (2003) original model that has inspired our study had the assumption that elements of spiritual leadership, namely vision, hope/faith and altruistic love has a significant effect on the meaning perceived by employees. Later Fry and his coresearchers reemphasized this positive relationship in their studies (Fry et al., 2005; Fry and Matherly, 2006; Malone and Fry, 2003, Fry et al., 2017). Besiders Fry's studies there are also studies applied by other researches regarding effects of spiritual leadership on the meaning perceived by employees. For example; Markow and Klenke's (2005) research on the relationship between main concepts of spiritual leadership theory, namely, personal meaning, calling, and organizational commitment found that meaning resulting from religiosity was not a perfect antecedent of calling, whereas meaning derived from self-transcendence come about as a result of religiosity. In addition, they found that calling was an important indicator of organizational commitment and acts as a mediator in the relationship between meaning and commitment. Being inspired by these studies the effect of spiritual leadership on organizational commitment has been examined and it is proposed that meaning perceived by individuals at work will have a mediator effect in spiritual leadership and organizational commitment relationship.Thus, first two hypothesis of this study are;

H1: Spiritual leadership behavior positively effects organizational commitment of employees $\mathrm{H} 2$ : The sense of meaning positively effects organizational commitment perceptions of employees.

H3: Meaning perceived by employees acts as a mediator between spiritual leadership behavior and organizational commitment of employees 


\section{METHODOLOGY}

\subsection{Sample and Data Collection}

In this study, easy sampling methodology was preffered in data collection in order to reach participants easily from the universities that we have previously established contacts. In the field research, face to face and online survey methods have been used. And exploratory factor analysis was used to test if the observed variables are loaded in the supposed dimensions. And SPSS analysis have been conducted encompassing correlation and regression analysis in order to test the hypothesis. Surveys were designed with five-point Likert Scale. The sample of the study was composed of Turkish academicians from different universities in Turkey. Academicians were choosen as the sample of the study with the assumption that their task identity composes some spiritual elements such as beng a role model for students, directing students for higher purposes, creating harmony among young student groups and promoting more confident and efficient young adults out of young students. Approximately, 800 questionnaries were delivered to academicians from different Turkish universities. The data collection period took six months. After this period 190 surveys that were usable in the analysis have been obtained. In our sample, more than $\% 23$ of applicants had 0-2, \%37 of the applicants had 2-5 years experience and \% 33 of the applicants had 5-10 years of experience, and \% 23 of the applicants were between the ages of 20-30 and \% 46 of the applicants were between the ages of 30-39, and \% 21 of the applicants were more than 40 years old and about $\% 57$ of the whole sample are male.

Moreover, Kaiser-Meyer-Olkin test was applied in order to test if the data was sufficient for further analysis or not. KMO result was found to be 0,920 and and Barlett score was found to be under 0,000 that can be considered as proper values for continuing with the factor analysis.

\subsection{Results}

In this study, the model atempting to explain the relationships among spiritual leadership sense of meaning and perceptions of organziational commitment perceptions of followers were tested. With the purpose of testing internal validity of the scales, factor analysis has been applied and after the factor analysis in order to test the reliability of the scales Cronbach's Alpha values were calculated. As a result of factor analysis, spiritual leadership items were loaded to two dimensions first, hope and altruism and the second vision. Hope and altruism questions were loaded in the same factor and vision questions were loaded as a second factor. So we 
named this first dimension as individual spirituality. And organizational commitment items were loaded to again two main dimensions first, continuance commitmeent second normative commitment. Cronbach Alpha values obtained from reliability analysis were in the expected levels. Cronbach's Alpha coefficients and the coefficients obtained from the factor analyzes are given in Table 1.

Table 1. Factor Loadings

\begin{tabular}{|c|c|c|c|c|c|c|}
\hline & 1 & 2 & 3 & 4 & 5 & $\begin{array}{c}\text { Cronbach } \\
\text { Alfa } \\
\end{array}$ \\
\hline SLHF3 & 0,955 & & & & & 0.960 \\
\hline SLHF7 & 0,939 & & & & & \\
\hline SLAL10 & 0,899 & & & & & \\
\hline SLAL12 & 0,869 & & & & & \\
\hline SLHF2 & 0,847 & & & & & \\
\hline SLHF8 & 0,819 & & & & & \\
\hline SLHF4 & 0,774 & & & & & \\
\hline SLAL11 & 0,773 & & & & & \\
\hline SLHF6 & 0,746 & & & & & \\
\hline SLHF1 & 0,692 & & & & & \\
\hline SLHF5 & 0,682 & & & & & \\
\hline SLV17 & & 1,003 & & & & 0.825 \\
\hline SLV16 & & 0,826 & & & & \\
\hline SLV15 & & 0,558 & & & & \\
\hline WSM19 & & & 0,88 & & & 0.814 \\
\hline WSM18 & & & 0,78 & & & \\
\hline WSM20 & & & 0,65 & & & \\
\hline WSM21 & & & 0,536 & & & \\
\hline NC71 & & & & 0,833 & & 0.760 \\
\hline NC70 & & & & 0,827 & & \\
\hline AC60 & & & & 0,802 & & \\
\hline AC61 & & & & 0,781 & & \\
\hline AC59 & & & & 0,748 & & \\
\hline NC68 & & & & 0,703 & & \\
\hline NC69 & & & & 0,688 & & \\
\hline CC65 & & & & & 0,905 & 0.707 \\
\hline CC64 & & & & & 0,875 & \\
\hline CC66 & & & & & 0,553 & \\
\hline
\end{tabular}

Extraction Method: Principal Component Analysis.

Rotation Method: Oblimin with Kaiser Normalization.

Table 2. Correlation Analysis

\begin{tabular}{llrrrrr}
\hline & & SL1 & SL2 & NC & CC & WSM \\
\hline SL1 & Pearson Correlation & 1 & & & & \\
SL2 & Pearson Correlation &, $739^{* *}$ & 1 & & & \\
NC & Pearson Correlation &, $405^{* *}$ &, $344^{* *}$ & 1 & & \\
CC & Pearson Correlation & 0,095 & 0,022 &, $155^{*}$ & 1 & \\
WSM & Pearson Correlation &, $302^{* *}$ &, $270^{* *}$ &, $425^{* *}$ &, $258^{* *}$ & 1 \\
\hline
\end{tabular}

** Correlation is significant at the 0.01 level (2-tailed).

* Correlation is significant at the 0.05 level (2-tailed). 
As seen in the table the most powerful correlations are seen between the two dimensions of spiritual leadership, namely SL, vision of the leaders and S2, which is the dimension encompassing faith and altruism of the leader. And astonishingly despite being positive, the least powerful correlations are between normative commitment and continuance commitment of the employers. Morover, regression analysis has been applied in order to test the hypothesis and understand direction of the relationships. The model of the research was tested with 6 different regression models as seen in Table 3. The conditions of Baron and Kenny (1986) have been applied in these models.

Table 3. Regression Analysis

\begin{tabular}{|c|c|c|c|c|c|c|c|c|c|c|c|c|}
\hline \multirow[b]{2}{*}{$\begin{array}{l}\text { Independent } \\
\text { Variable }\end{array}$} & \multicolumn{2}{|c|}{$\begin{array}{c}\text { Model } 1 \\
\text { Affective } \\
\text { Commitment }\end{array}$} & \multicolumn{2}{|c|}{$\begin{array}{c}\text { Model } 2 \\
\text { Continuance } \\
\text { Commitment }\end{array}$} & \multicolumn{2}{|c|}{$\begin{array}{c}\text { Model 3 } \\
\text { Affective } \\
\text { Commitment }\end{array}$} & \multicolumn{2}{|c|}{$\begin{array}{c}\text { Model } 4 \\
\text { Continuance } \\
\text { Commitment }\end{array}$} & \multicolumn{2}{|c|}{$\begin{array}{c}\text { Model 5 } \\
\text { Affective } \\
\text { Commitment }\end{array}$} & \multicolumn{2}{|c|}{$\begin{array}{c}\text { Model } 6 \\
\text { Continuance } \\
\text { Commitment }\end{array}$} \\
\hline & Beta & $\mathbf{t}$ & Beta & $\mathbf{t}$ & Beta & $\mathbf{t}$ & Beta & $\mathbf{t}$ & Beta & $\mathbf{t}$ & Beta & $\mathbf{t}$ \\
\hline Constant & 2,28 & $13,59 * * *$ & 2,685 & $10,51 * * *$ & 1,647 & $6,67 * * *$ & 3,989 & $10,79 * * *$ & 1,29 & $5.08 * * *$ & 3,798 & $9,58 * * *$ \\
\hline $\begin{array}{l}\text { Individual } \\
\text { Spirituality }\end{array}$ & 0,2 & $3,314 * *$ & 0,212 & $2,298 *$ & & & & & 0,152 & $0,152 *$ & 0,159 & 1,74 \\
\hline $\begin{array}{l}\text { Spritual } \\
\text { Leadership } \\
\text { Vision }\end{array}$ & 0,066 & 1,01 & 0,191 & $1,908 *$ & & & & & 0,048 & 0,048 & 0,215 & $2,197^{*}$ \\
\hline Meaning & & & & & 0,39 & $6.37 * * *$ & 0.335 & $3.666^{*}$ & 0,306 & $4,99 * * *$ & 0,346 & $3.60 * * *$ \\
\hline $\mathrm{F}$ & & 18,519 & & 2,687 & & 40,582 & & 13,441 & & 22,008 & & 6.181 \\
\hline $\begin{array}{l}\text { Adjusted R } \\
\text { Square }\end{array}$ & & 0.159 & & 0.018 & & 0.176 & & 0.062 & & 0.255 & & 0.076 \\
\hline Sign. & & 0.000 & & 0,05 & & 0.000 & & 0.000 & & 0.000 & & 0.000 \\
\hline
\end{tabular}

In the first and second regression models we tried to test Hypothesis 1, namely spiritual leadership has a statistically significant effect on organziational commitment. On the model 1 we saw that this effects is possible on affective commitment through the first subdimension of spiritual leadership namely the dimension including hope/faith and altruism items (Adjusted R Square $=0.158, \mathrm{Sig}=0.000)$. And in the second model we saw that although not very powerful both dimensions of spiritual leadership are affective on continuance commitment (Adjusted $\mathrm{R}$ Square $=0.018, \mathrm{Sig}=0.05$ ). So Hypothesis 1 is accepted. In order to test the second hypothesis, regression model 3 and regression model 4 have been applied. And our hypothesis suggesting that meaning has a positive effect on organziational commitment perceptions of followers has been confirmed. In fact meaning was effective on both affective commitment (Adjusted $\mathrm{R}$ Square $=0.176, \mathrm{Sig}=0.000$ ) and continuance commitment (Adjusted R Square=0.062, Sig= 
0.000). And in model 5 (Adjusted R Square $=0.255$, Sig= 0.000) and in model 6 (Adjusted R Square=0.076, Sig=0.000), our third hypothesis has been tested. And it is seen that although not a full mediator, the sense of meaning can be accepted as a partial mediator in the relationship between spritual leadership and organizational commitment. In fact, in model 5, the effect of individual spirituality diminished and in model 7 it was disappeared. But the positive effect of vision continued both in model 5 and in model 6 . This results confirm the assumption of spiritual leadership scholars that creating meaning is an important aspect of spiritual leadership (Fairholm 1997, Fry 2003) which can be so powerful in directing organizational members' attitudes regarding their Organizational commitment. And this effect can be so powerful on Organizational commitments of individuals so that it can overshadow the effects of dimensions of spiritual leadership. That is to say, spiritual leadership makes the work of the employees so meaningful that the effect of this sense of meaning on organizational commitment eclipses the effect of spiritual leadership on organizational commitment.

\section{DISCUSSION}

In the last decades, myriad approaches of leadership come about. In their study regarding these different leadership styles. As mentioned before, as it is pervasively accepted spiritual leadership theory is based on Fry's (2003) model which is an intrinsic motivation model incorporating vision, hope/faith, and altruistic love, and spiritual well-being concepts (Fry, 2003, Fry and Cohen 2008). Later Fry (2005b) developed spiritual leadership approach by adding the concepts of positive individual health, psychological well-being, ethical wellbeing, and life satisfaction. And these concepts provided a unaminity on the norms, attitudes, and beliefs required for positive human development. In organizations, the employer's respect for the private and intimate sphere of the worker, the worker's respect for the value ranges that the worker values, and the way in which the employee gives the space and the opportunity for the employee to live his own spirituality are indications that he finds the spirituality and the search for meaning in the work environment.

By connecting people to others in the organization and to the employee's own selves, and to the transcendent high power, spiritual leader contributes to wholeness of individuals and encourage them to seek meaningful work, thus directing to a high order goal and meaning (Hudson, 2014). Moreover, spiritual leaders give purpose to the lives of their followers by the help of meaningful work, transcendence in the workplace, altruism among organization members, and sense of community. When the extant literature is investigated, although scarce 
in numbers, we can come accross some studies investigating similar models. For example, Rego and Pina e Cunha (2008) investigated the effects of workplace spirituality on organizational commitment and similar to our results they found that spiritual leadership is more effective on affective commitment rather than continuance commitment. Similarly, Usman and Danish (2010) examined leadership spirituality in banking sector, in parallel with our results in their study spiritual leadership has found to be very important in explaining the affective commitment of individuals. And Kazemipour, Amin and Pourseidi (2012) also investigated effects of spiritual leadership and they showed that workplace spirituality is effective on affective commitments of nurses.

In this study, we saw that spiritual leadership positively effects organizational commitment is possible on affective commitment through the first subdimension of spiritual leadership, namely the dimension including hope/faith and altruism items. And its effect on continuance commitment come about through vision subdimension. In fact continuance commitments is a more rational commitment type, it is about rationalizing to carry on working in a certain organization. So the positive relationship between vision and continuance commitment is not astonishing. Having a clear and meaningful vision and directing people towards that vision, a spiritual leader can be effective on continuance commitment of his followers through the subdimension of vision. Moreover, in our study, it is confirmed that the sense of meaning has a statistically significant effect on both affective and continuance commitment. Moreover, as it is supposed in the research model, meaning has been found to be acting as a partial mediator in the relationship between spritual leadership and organizational commitment. In fact, the positive effect of spiritual leadership on organizational commitment occured mostly owing to the hope/faith and altruistic behaviors of leader and vision dimension seems to effect continuance commitment more strongly. Since vision items were more related to tangible goals directing people towards organizational good, the part of organizational commitment rationalizing one's reasons to stay in the organization, namely continuance commitment is effected predominantly by vision compared to the case in affective commitment.

\section{MANAGERIAL IMPLICATIONS}

The employer's respect for the private and private space of the worker, his approach with respect for the employee's valuable values and his / her ability to enable the employee to live his own spirituality are indicators of the spirituality and the search for meaning in the work 
environment. It is an effective and meaningful beginning for companies to have knowledge about the demographic and ideological structures of their employees, to have an idea of their employees' lifestyles, family structures and social relations, at least to create mechanisms wherein they will experience their spirituality in the work environment. In fact, all of the attempts that creates on opening space for spirituality are expected to have great benefits in the long run. At this point, every attempt that will nurture the spirituality of the individuals will actually strengthen their loyalty to the institution, enable the individual to work selflessly for the institution and contribute to the longer plans of the institution.

The possibility of employees to individualize their fields of work, the states that the individual is not exposed to a uniform working style or working environment is the details that can help the individual to find his/her work that feeds his spirituality more meaningful. Another way for employees to experience meaning in the business environment is to make the work less stressful and more enjoyable. Another way to make employees see their work more meaningful is their actual participation in decisions and processes. Providing employees' participation in decisions or processes through ideas and feedback collection platforms in many companies is one of the applications that feeds the sense of meaning and connectedness in the employee's business environment (Narc1kara, 2018: 21).

\section{FURTHER STUDIES AND LIMITATIONS}

In this study, the effect of spiritual leadership in creating meaning at work has been confirmed in Turkish context. Moreover, the study has confirmed that by embracing spiritual leadership behavior and by creating meaning through this leadership style managers can create organizational commitment on the side of their followers. However, the study also has some limitations, first of all the sample was obtained by easy sampling method, so a greater number of sampling data with higher representativenes will make the study more meaningful. Furtermore, the same model can be replicated on the people working in different sectors. And cross cultural studies can be carried out with the aim of comparing the results of the model in different cultural settings. And some other spiritual leadership concepts such as interconnectedness, membership or sense of calling can also be tested as mediator actors in our model. 


\section{REFERENCES}

Alimudin, A., Septian, D., Sasono, A. D., \& Wulandari, A. (2017). Effect of Spiritual Leadership to Organizational Culture and Employee's Loyalty. Jurnal Terapan Manajemen Dan Bisnis, 3(2), 76-86.

Ashmos, \& Duchon (2000). Spirituality at work: A conceptualization and measure. Journal of Management Inquiry, 9(2), 134-145.

Baykal, E., \& Zehir, C. (2018). Mediating effect of psychological capital on the relationship between spiritual leadership and performance. Economics and Management.

Campbell, J. K., \& Hwa, Y. S. (2014). Workplace Spirituality and Organizational Commitment Influence on Job Performance among Academic Staff. Jurnal Pengurusan (UKM Journal of Management), 40.

Chen, C. Y., \& Li, C. I. (2013). Assessing the spiritual leadership effectiveness: The contribution of follower's self-concept and preliminary tests for moderation of culture and managerial position. The Leadership Quarterly, 24(1), 240-255.

Coma, J. M. (2007). Spiritual practice: a literature review related to spiritual health and health outcomes. Holistic nursing practice, 21(5), 224-236.

Crossman, J. (2007). The spirit of business: Spiritualising otherwise secular work and learning contexts. International Employment Relations Review, 13(2), 1.

DeVost, R. (2010). Correlation between the leadership practices of lead ministers and the workplace spirituality of their churches as reported by church members. Andrews University). ProQuest Dissertations and Theses, Retrieved from http://search.proquest.com/docview/871103857?accountid=10559.

Fairholm, G. W. (1996). Spiritual leadership: Fulfilling whole-self needs at work. Leadership \& Organization Development Journal, 17(5), 11-17.

Fernando, M. \& Nilakant, V. (2008), “The place of self-actualisation in workplace spirituality: evidence from Sri Lanka", Culture and Religion, Vol. 9 No. 3, pp. 233-249.

Fini, A. A. S., \& Abmal, Y. (2017). Examine the Relationship between Organizational Happiness and Organizational Spirituality with Organizational Commitment in Administrators and Teachers. Journal of Exploratory Studies in Law and Management, 4(2).

Frisdiantara, C., \& Sahertian, P. (2013). The spiritual leadership dimension in relation to other value-based leadership in organization. Ideology and Leadership, 11.

Fry, L. W. (2003). Toward a theory of spiritual leadership. The Leadership Quarterly, 14(6), 693-727.

Fry, L. W., \& Cohen, M. P. (2009). Spiritual leadership as a paradigm for organizational transformation and recovery from extended work hours cultures. Journal of business ethics, 84, 265-278.

Fry, L. W., \& Matherly, L. L. (2006, August). Spiritual leadership and organizational performance: An exploratory study. In Annual Meeting of the Academy of Management,(11-16 Ağustos) Atlanta-Georgia.

Fry, L. W., Vitucci, S., \& Cedillo, M. (2005). Spiritual leadership and army transformation: Theory, measurement, and establishing a baseline. The leadership quarterly, 16(5), 835-862.

Fry, L., \& Kriger, M. (2009). Towards a theory of being-centered leadership: Multiple levels of being as context for effective leadership. Human Relations, 62(11), 1667-1696.

Fry, L. W., \& Slocum Jr, J. W. (2008). Maximizing the triple bottom line through spiritual leadership. Organizational dynamics, 37(1), 86-96. 
Giacalone, R., \& Jurkiewicz, C. (2003). Toward a science of workplace spirituality. In R. Giacalone, \& C. Jurkiewicz (Eds.), Handbook of workplace spirituality and organizational performance (pp. 3-28). Armonk, NY7 Sharpe.

Gilbreath, B., \& Benson, P. G. (2004). The contribution of super- visor behaviour to employee psychological wellbeing. Work \& Stress, 18, 3, 255-266.

Greenleaf, S. (1977). Servant leadership. New York: Paulist Press.

Gündüz, Ş. (2017). The relationship between spiritual leadership and organizational cynicism: The moderating effect of emotional intelligence. Doğuş University Journal, 18, 2, 117-132.

Hudson, R. (2014). The question of theoretical foundations for the spirituality at work movement. Journal of Management, Spirituality \& Religion, 11, $27 \mathrm{e} 44$.

Kazemipour, F., Amin, S. M., \& Pourseidi, B. (2012). Relationship between workplace spirituality and organizational citizenship behavior among nurses through mediation of affective organizational commitment. Journal of Nursing Scholarship, 44(3), 302-310

Kolodinsky, R.W., Giacalone, R.A. \& Jurkiewicz, C.L. 2008. Workplace values and out-comes: Exploring personal, organizational, and interactive workplace spirituality. Journal of Business Ethics 81: 465-80.

Kouzes, J. M., \& Posner, B. Z. (2002). The leadership challenge. San Francisco: Jossey- Bass.

Kriger, M. and Seng, Y. (2013), "Leadership with inner meaning: a contingency theory of leadership based on the worldviews of five religions”, The Leadership Quarterly, Vol. 16 No. 5, pp. 771-806.

Malone, P., \& Fry, L. W. (2003). Transforming schools through spiritual leadership: A field experiment. In Annual Meeting of the Academy of Management,(1-6 Ağustos). Seattle-Washington.

Mansor, N., Ismail, A. H., Alwi, M. A. M., \& Anwar, N. (2013). Relationship between spiritual leadership and organizational commitment in Malaysians' oil and gas industry. Asian Social Science, 9(7), 179.

Markow, F., \& Klenke, K. (2005). The effects of personal meaning and calling on organizational commitment: An empirical investigation of spiritual leadership. International Journal of Organizational Analysis, 13(1), 8-27.

Meyer, J. P., \& Allen, N. J. (1991). A three-component conceptualization of organizational commitment. Human 109 Resource Management Review, 1, 61-89. http://dx.doi.org/10.1016/1053-4822(91)90011-Z

Mousa, M., \& Alas, R. (2016). Workplace spirituality and organizational commitment: A study on the public schools teachers in Menoufia (Egypt). African Journal of Business Management, 10(10), 247-255.

Narcıkara, E. (2017). Spiritüel Liderlik Davranışının Algılanan Performans Üzerine Etkisi (Yayımlanmamış doktora tezi). Yıldız Teknik Üniversitesi, İstanbul.

Narcıkara, E. B. (2018). Spiritüelite (Ruhsallık) ve iş ortamında anlam arayışı. Alanya Akademik Bakış, 2(1), 1125.

Paloutzian, R. F., Emmons, R. A., \& Keortge, S. G. (2003). Spiritual well-being, spiritual intelligence, and healthy workplace policy. In R. A. Giacolone, \& C. L. Jurkiewicz (Eds.), Handbook of workplace spirituality and organizational performance (pp. 123-137). New York7 M.E. Sharpe.

Reave, L. (2005). Spiritual values and practices related to leadership effectiveness. The leadership quarterly, 16(5), 655-687.

Rego, A., \& Pina e Cunha, M. (2008). Workplace spirituality and organizational commitment: an empirical study. Journal of organizational change management, 21(1), 53-75. 
Rouhoma, H. M., Dhar, B. K., Ali, K., \& Osman, M. M. (2018). Constructing model to explore the influence of Religiosity and Spirituality on Organizational Performance through Organizational Commitment. Al'ABQARI: Journal of Islamic Social Sciences and Humanities, 16, 11-30

Sreejesh S, Tavleen N (2011). Antecedents and Consequences of Employee loyalty towards the Organization: Empirical Evidence from Indian Software Industry. IJMS 18(2).

Sušanj, Z., \& Jakopec A. (2012). Fairness perceptions and job satisfaction as mediators of the relationship between leadership style and organizational commitment. Psychological Topics, 21(3), 509-526.

Usman, A., \& Danish, R. Q. (2010). Leadership spirituality in banking professionals and its impact on organizational commitment. International Journal of Business and Management, 5(3), 185.

Vandenberghe, C. (2011), "Workplace spirituality and organizational commitment: an integrative model”, Journal of Management, Spirituality and Religion, Vol. 8 No. 3, pp. 211-232.

Wulff, D. M. (1996). Psychology of religion: Classic and contemporary. New York: Wiley.

Zinnbauer, B.J., Pargament, K. I., Cole, B., Rye, M., Butter, E.M., Belavich, T. G., Hipp, K.M. and Scott, A.B, (1997). Religion and Spirituality: Unfuzzying the Fuzzy, Journal for the Scientific Study of Religion, (36)4, 549-564. 